\title{
A NOÇÃO DE CONFLITO E OPOSIÇÃO NA CARACTERIZAÇÃO DE HANNA
}

\author{
THE CONCEPT OF CONFICT AND OPOSITION IN THE CHARACTERIZATION \\ OF HANNA
}

\section{Ederson Vertuan}

Universidade Estadual de Londrina

\section{Patrícia Josiane Tavares da Cunha Fuza}

Universidade Estadual de Londrina

RESUMO: O propósito desta investigação é analisar a personagem Hanna do filme homônimo e estabelecer o número de características dadas a ela com base no conceito de conflito e oposição. A hipótese é a de que quanto mais elementos da personagem são empregados com base no conceito de conflito e oposição durante o processo de caracterização, maior será a carga emocional envolvida nas ações e decisões da personagem dentro da estória.

PALAVRAS-CHAVE: Personagens ficcionais; Conflito; Hanna.

ABSTRACT: The purpose of this investigation is to analyze the character Hanna from the movie of the same name and establish the number of characteristics given to her which are based in the concept of conflict and opposition. It is hypothesized that the more elements of a given character are created based in the concept of conflict and opposition during the characterization process, the more emotionally charged will be the actions and decisions of the character in the story.

KEYWORDS: Fictional Characters; Conflict, Hanna. 


\section{Revista do SELL}

v. $4, n^{\circ} .2$

ISSN: $1983-3873$

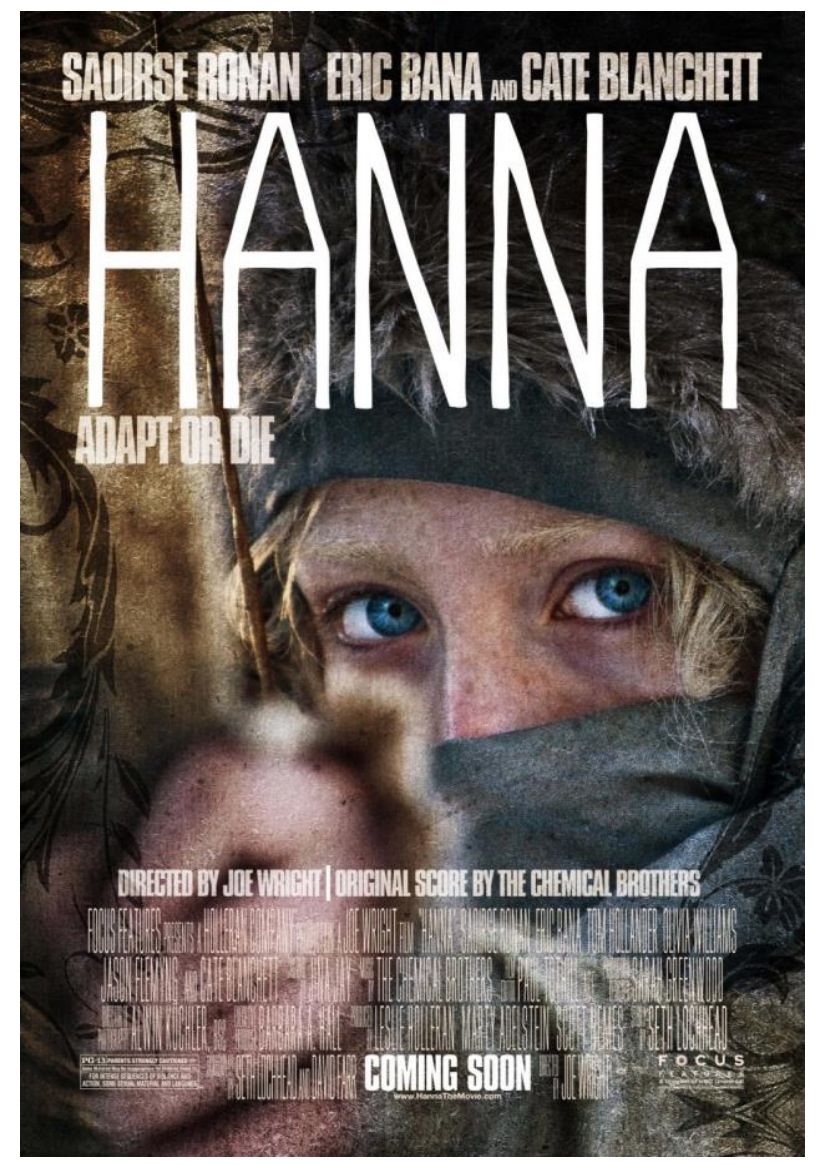

Figura 1: Pôster promocional de Hanna.

Hanna é uma jovem de dezesseis anos treinada por seu pai Erik Heller para ser uma assassina. Erik a cria isolada em uma floresta finlandesa, longe da eletricidade e do mundo moderno. Seu desejo é vingar-se de Marissa Wiegler, uma agente da C.I.A., que assassinou Johanna, mãe de Hanna. Mas Erik não obriga a filha a aceitar essa "missão". Hanna possui dois desejos principais: matar Marissa Wiegler e conhecer o mundo exterior. Ela, então, decide seguir com o plano de vingança e ativa um transmissor que informa Marissa Wiegler sobre sua localização.

O filme Hanna, lançado em 2011, foi dirigido por Joe Wright e estrelado por Saoirse Ronan. Tanto o diretor quanto a atriz afirmam, em entrevistas, que uma das principais razões para seus envolvimentos no projeto do filme Hanna foi a admiração que sentiram pela protagonista após a leitura do roteiro de Seth Lockhead. No pôster acima, Hanna, uma adolescente de olhos azuis, veste-se com roupas de inverno que lembram um uniforme ninja e aponta um arco e flecha para um alvo que, pela expressão de seu olhar, parece ameaçá-la. A imagem da heroína contém uma oposição de ideias: uma adolescente de aparência delicada é, na imagem, associada ao manuseio de uma arma 


\section{Revista do SELL}

v. $4, n^{\circ} .2$

ISSN: $1983-3873$

rústica. A figura da heroína passa a causar curiosidade pelo caráter extraordinário da situação que ilustra.

Tanto na ficção literária como na cinematográfica, o papel de herói armado com arco e flecha ou vestido como ninja é dado, na maior parte das vezes, a personagens do sexo masculino, cuja virilidade é marcada por sobrancelhas negras e um rosto mal humorado. Um exemplo desse tipo de personagem seria o herói Robin Hood, presente no romance Ivanhoé (1820), de Sir Walter Scott, e interpretado por Russell Crowe em filme de 2010:

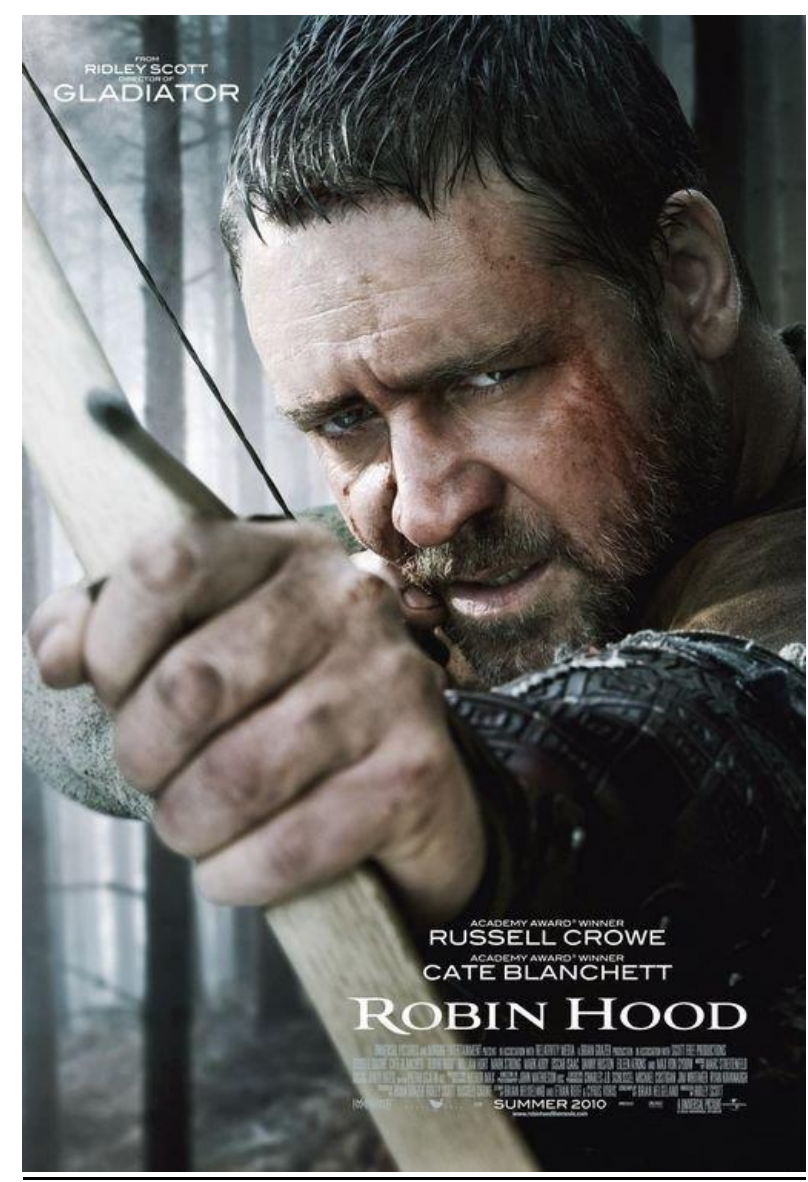

Figura 2: Pôster de Robin Hood.

Escritores e roteiristas, no entanto, há algum tempo tem feito escolhas diferentes ao criar novos heróis para suas estórias, visando emprestar um caráter "novo" a seus personagens principais. As novas escolhas podem aparecer em muitos dos elementos que compõem a personagem, a começar pelo seu gênero. Um exemplo de tipo novo de protagonista ocorre em Alien (1979), em que o estereótipo da mulher frágil é quebrado 


\section{Revista do SELL}

v. $4, n^{\circ} .2$

ISSN: $1983-3873$

pela caracterização andrógina da heroína Ellen Ripley. A opção dos produtores David Giller e Walter Hill por uma protagonista feminina para a estória de Alien foi intencional, de modo que sua exposição ao perigo pudesse contribuir para aumentar a resposta emocional (suspense) do expectador. A ideia, contudo, não é nova: o gênero gótico já recorre a essa técnica desde O Castelo de Otranto (1764), de Horace Walpole, embora a heroína de romances góticos permaneça frágil e dependente da proteção de um herói masculino para sobreviver aos perigos da estória. No caso de heroínas como Ellen Ripley, pelo contrário, a protagonista feminina assume a responsabilidade por sua própria proteção, adotando algumas características antes restritas a personagens masculinos, como a capacidade de manusear armas e de apresentar maior resistência física e emocional. Tudo isso faz de Ripley uma personagem mais complexa, diferente e que se sobressai dentre os muitos heróis masculinos de estórias de ficção científica. Nesse sentido, pode-se dizer que Hanna vai além de Ripley: na primeira, o apelo emocional é ainda mais acentuado pela juventude da protagonista, que exacerba as ideias de fragilidade e inocência. A imagem de Hanna é "tensa", pois contrasta, simultaneamente, duas ideias distintas, a da adolescente frágil e a do guerreiro embrutecido. Compare-se, por exemplo, o pôster de Hanna com o de outro filme, produzido três anos antes: 


\section{Revista do SELL}

v. $4, n^{\circ} .2$

ISSN: $1983-3873$
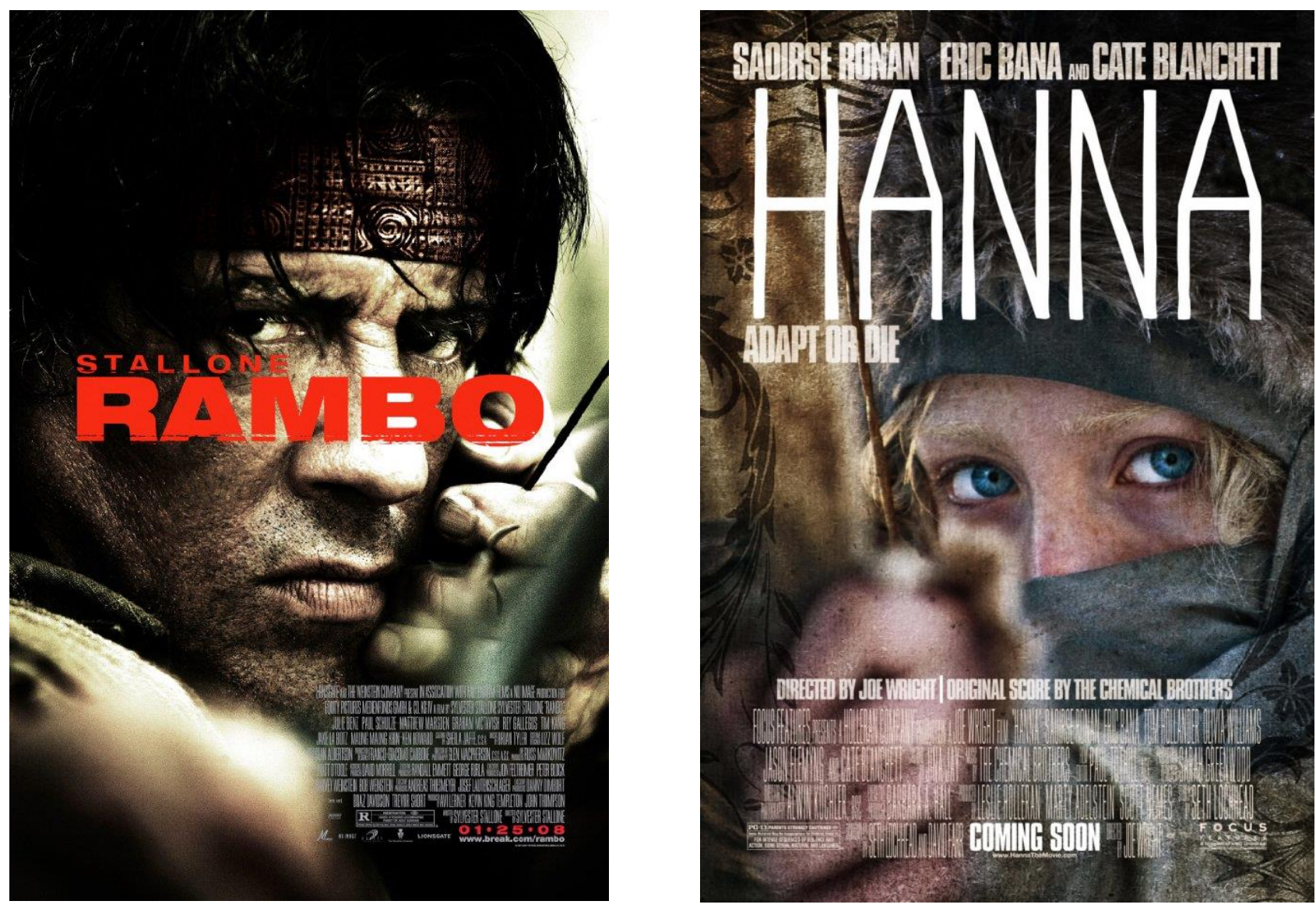

Figura 3: Pôster de Rambo IV.

Pode não haver algo de muito extraordinário no fato de Rambo empunhar armas de qualquer tipo, pois é exatamente isso o que todo o fã do herói espera dele. E sendo ele Rambo, o que se espera é que ele o faça, de preferência, em excesso. No caso de Hanna, pelo contrário ${ }^{1}$, a tendência é que o expectador não esteja habituado a associar a ideia de uma adolescente loira de olhos azuis à de uma espiã assassina. Hanna, assim como Ripley, é uma personagem que quebra os estereótipos do guerreiro viril e da adolescente inocente, surpreendendo pela novidade da associação inesperada de ideias.

Segundo Seger (1999, p. 157), "a habilidade de incorporar qualidades opostas [...] é uma das marcas do [...] grande personagem". ${ }^{2}$ Personagens concebidos a partir dessa união de ideias opostas tornam-se memoráveis porque passam a ser capazes de despertar curiosidade e emoção no público. Uma análise de personagens como Hanna pode ajudar a estabelecer a existência ou não de uma regularidade na aplicação do

\footnotetext{
${ }^{1}$ Hanna pode ser entendida como uma espécie de "Rambo" feminina: além da semelhança entre os pôsteres promocionais, até mesmo os sons dos nomes são semelhantes (Rambo/Hanna) e possuem o mesmo número de letras (5), sugerindo uma intenção, possivelmente, deliberada de associação entre esses personagens por parte de Seth Lockhead, criador de Hanna.

${ }^{2}$ The ability to incorporate opposite qualities $[\ldots]$ is one of the marks of $[\ldots]$ the great character.
} 


\section{Revista do SELL}

v. $4, n^{\circ} .2$

ISSN: $1983-3873$

conceito de oposição em suas diferentes dimensões. Pode-se pensar, de início, que quanto mais elementos da personagem são criados com base na noção de conflito e oposição durante o processo de caracterização, maior o seu apelo emocional e capacidade de despertar curiosidade no público.

Em seu livro The Art of Dramatic Writing, Egri (2004) afirma que um personagem ficcional possui três dimensões: a fisiológica, a sociológica e a psicológica. Esses elementos estabelecem o que Egri (2004) chama de estrutura óssea de um personagem. O formulário a seguir é relativo aos aspectos fisiológicos, sociológicos e psicológicos de Hanna no início da estória e como podem ser preenchidos segundo o formato apresentado no livro de Egri (2004):

\section{FISIOLOGIA}

\begin{tabular}{|c|c|}
\hline 1. Sexo: & Feminino \\
\hline 2. Idade: & 16 (no roteiro, 14) \\
\hline 3. Altura: & Loiro, olhos azuis, Branca. \\
\hline 4. Cor de cabelos, olhos, pele: & Ereta. \\
\hline 5. Postura: & $\begin{array}{c}\text { Boa aparência, peso ideal, limpa, } \\
\text { agradável. O desenho da cabeça, da face e } \\
\text { dos membros normal, agradánel. Ela tem o } \\
\text { cabelo desarrumado, despenteado. }\end{array}$ \\
\hline 7. Deficiência: & $\begin{array}{c}\text { Nenhuma } \\
\text { 8. Hereditariedade: }\end{array}$ \\
\hline
\end{tabular}

Tabela 1: Formulário de Egri (2004) preenchido com informações sobre Hanna. 


\section{Revista do SELL}

v. $4, n^{\circ} .2$

ISSN: 1983-3873

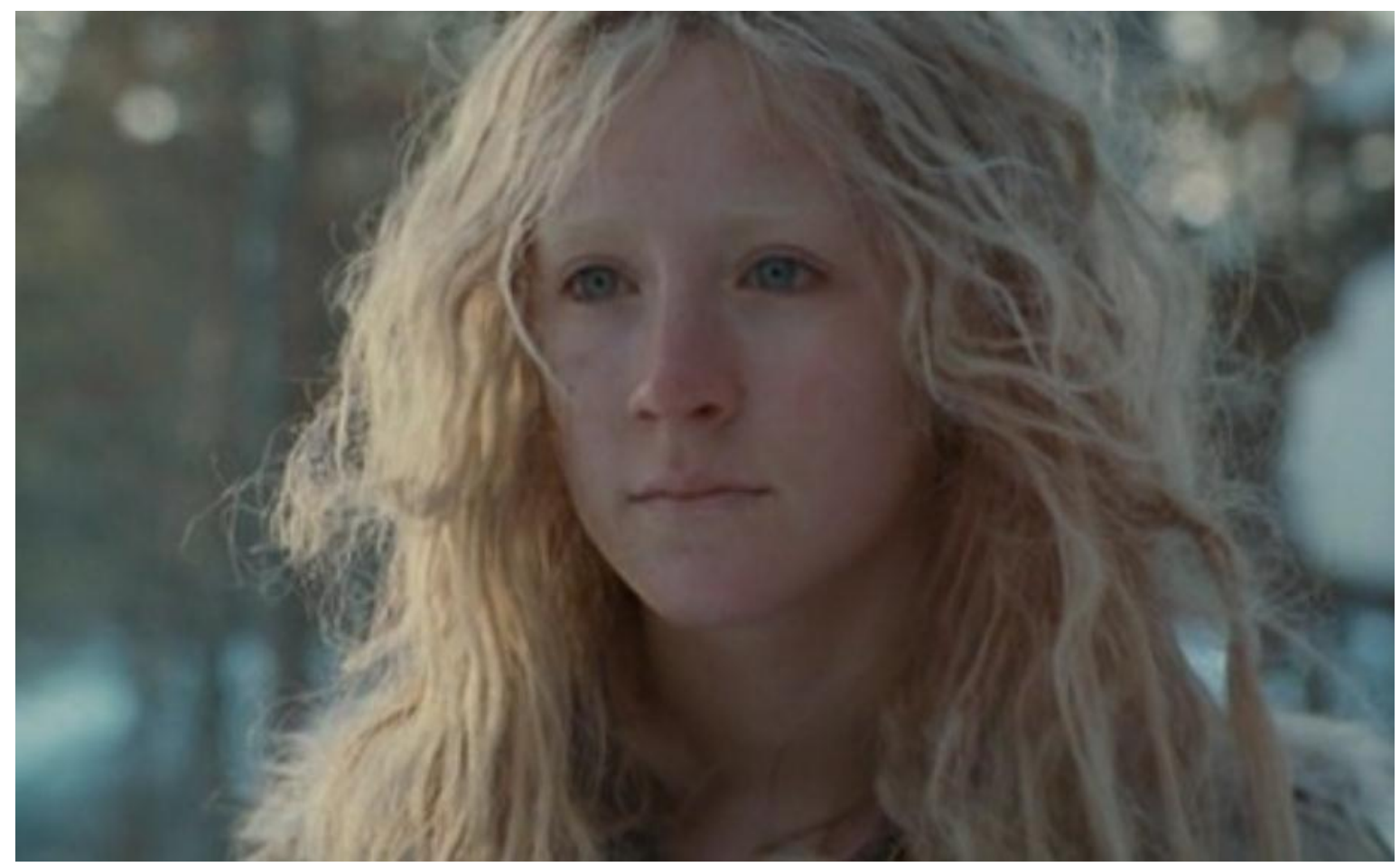

Figura 4: O cabelo despenteado de Hanna empresta a ela uma aura de conto de fadas, mas também simboliza a peculiaridade de seu caráter.

\begin{tabular}{|c|c|}
\hline \multicolumn{2}{|c|}{ SOCIOLOGIA } \\
\hline 1. Classe: & Baixa. \\
\hline 2. Ocupação: & $\begin{array}{l}\text { Nenhuma ocupação formal. Ela é treinada } \\
\text { para ser uma assassina. }\end{array}$ \\
\hline 3. Educação: & $\begin{array}{l}\text { Nenhuma educação formal. Ela foi ensinada } \\
\text { pelo pai. "Ensinada em casa, Hanna fala } \\
\text { muitas línguas, como Inglês, Alemão, Italiano, } \\
\text { Árabe e Espanhol" (HANNA..., 2012), lê os } \\
\text { contos dos irmãos Grimm e tem vasto } \\
\text { conhecimento enciclopédico. Ela tem aptidões } \\
\text { de sobrevivência e é "proficiente em artes } \\
\text { marciais, boxe, luta de rua e armas" } \\
\text { (HANNA..., 2012). }\end{array}$ \\
\hline 4. Vida doméstica: & $\begin{array}{l}\text { Sua mãe está morta. Ela é treinada pelo pai, } \\
\text { Erik Heller, um ex-agente da C.I.A. Hanna é } \\
\text { solteira. }\end{array}$ \\
\hline 5. Religião: & Nenhuma \\
\hline 6. Raça, nacionalidade: & Branca. Sua nacionalidade é desconhecida. \\
\hline 7. Lugar na comunidade: & $\begin{array}{l}\text { Ela vive com seu pai em uma floresta da } \\
\text { Finlândia. }\end{array}$ \\
\hline 8. Afiliações políticas: & Nenhuma \\
\hline 9. Diversões, hobbies: & $\begin{array}{l}\text { Ela lê os contos dos irmãos Grimm, } \\
\text { ouve as leituras que seu pai faz de uma } \\
\text { enciclopédia e pratica a caça. }\end{array}$ \\
\hline
\end{tabular}

Tabela 2: Formulário de Egri (2004) preenchido com informações sociológicas sobre Hanna. 
Revista do SELL

v. $4, n^{\circ} .2$

ISSN: $1983-3873$

\begin{tabular}{|c|c|}
\hline \multicolumn{2}{|c|}{ PSICOLOGIA } \\
\hline 1. Vida sexual, padrões morais: & Hanna não tem vida sexual ativa aparente. \\
\hline 2. Premissa pessoal, ambição: & $\begin{array}{c}\text { Hanna quer matar a mulher que assassinou } \\
\text { sua mãe. Ela também quer conhecer o } \\
\text { mundo. }\end{array}$ \\
\hline 3. Frustrações, principais decepções: & $\begin{array}{c}\text { Seu pai se recusa a deixá-la conhecer o } \\
\text { mundo até sentir que ela está pronta e } \\
\text { independente. }\end{array}$ \\
\hline 4. Temperamento: & Calmo \\
\hline 5. Atitude frente à vida: & Militante. \\
\hline 6. Complexos: & $\begin{array}{l}\text { Hanna não tem obsessões, inibições, } \\
\text { superstições ou fobias aparentes. }\end{array}$ \\
\hline 7. Ambiversa: & Sim. \\
\hline 8. Habilidades: & $\begin{array}{l}\text { Hanna fala Inglês, Alemão, Italiano, Árabe e } \\
\text { Espanhol. Ela é proficiente em armas e em } \\
\text { artes marciais. }\end{array}$ \\
\hline 9. Qualidades: & Imaginação. \\
\hline 10. I.Q.: & Nenhuma referência é feita. \\
\hline
\end{tabular}

Tabela 3: Formulário de Egri (2004) preenchido com informações psicológicas sobre Hanna.

\section{CONFLITO E OPOSIÇÃO EM PERSONAGENS FICCIONAIS}

Seger (1999) recomenda a escritores e roteiristas a deliberada inclusão do conflito em suas estórias, sob pena de se criarem personagens "planos e brandos, [pois] grandes personagens são construídos sob a noção de oposição" (SEGER, 1999, p. 151)³. Esta oposição pode acontecer entre o desejo de um personagem e os obstáculos que dificultam sua obtenção, que podem ser de tipo externo, como o conflito com outro personagem, ou interno, como o conflito da personagem com o medo.

Outra maneira de se referir ao pensamento oposicional, segundo Seger (1999), consiste no termo "pensamento janusiano", uma referência ao deus Janus, que é, muitas vezes, representado com duas faces. O pensamento janusiano consiste em "conceber duas ou mais ideias, imagens ou conceitos opostos ou aparentemente contraditórias de modo simultâneo" "(ROTHENBERG apud SEGER, 1999, p. 152) e é responsável por ajudar o escritor a criar "múltiplas imagens [...], estórias e personagens que vão todos acontecer na tela ao mesmo tempo"5 (SEGER, 1999, p. 152). O pensamento oposicional pode ser definido como "a consideração de duas ideias que são opostas umas às outras"

\footnotetext{
${ }^{3}$ Flat and bland. Why? Because great characters are built on the concept of opposition. Todas as traduções são dos autores desse estudo.

${ }^{4}$ Conceiving two or more opposite or seemingly contradictory ideas, images or concepts simultaneously.

${ }^{5}$ Multiple images, ideas, stories, and characters that are all going to happen on screen at the same time
} 


\section{Revista do SELL}

v. $4, n^{\circ} .2$

ISSN: $1983-3873$

$\left(\right.$ SEGER, 1999, p. 154) ${ }^{6}$ e sua aplicação ocorre quando duas ideias opostas são apresentadas ao mesmo tempo, na mesma cena ou no mesmo personagem.

Um roteirista pode aplicar o pensamento oposicional ao desenvolver o que acontece entre o primeiro plano e o plano de fundo de uma cena. Um exemplo de cena baseada nessa ideia seria a de uma mulher que acredita estar a salvo no primeiro plano, sem perceber que uma porta se abre lentamente atrás dela (plano de fundo). O pôster do filme O Quarto do Pânico (2002), exemplifica a aplicação do pensamento janusiano, que potencializa o efeito de tensão e suspense da cena:

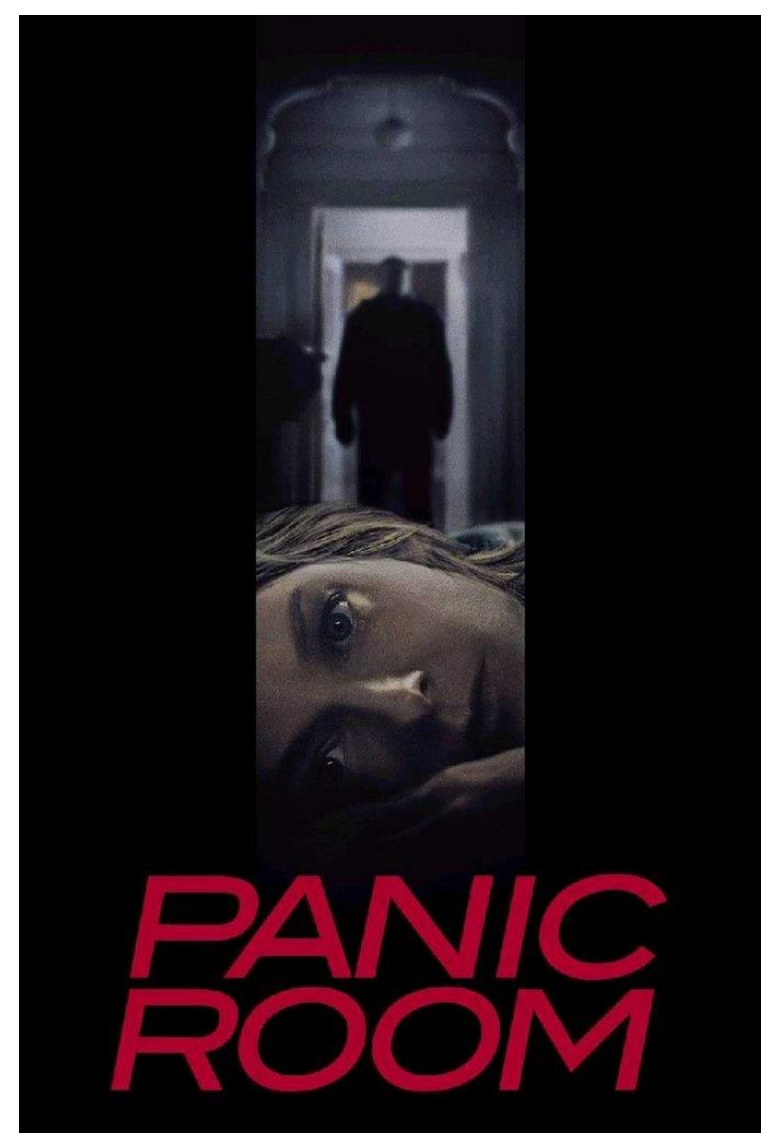

Figura 5: $O$ expectador imediatamente sente emoção (medo, suspense) com a situação ilustrada na cena.

De acordo com Seger (1999), o grande personagem lida com pensamentos, desejos e características opostas. Há personagens que incorporam, ao mesmo tempo, sabedoria e tolice ( $A$ Vida é Bela); introspecção e ação social (Gandhi); humildade e

\footnotetext{
${ }^{6}$ Considering two ideas that are opposed to one another.
} 


\section{Revista do SELL}

v. $4, n^{\circ} .2$

ISSN: $1983-3873$

orgulho (Coração Valente); agressão e cuidado ( $O$ Exterminador do Futuro) e masculinidade e feminilidade (Alien, O Exteminador do Futuro). Em estórias de ficção, o conflito é importante. É ele que "trás vida ao drama" (SEGER, 1999, p. 164):7

[O] conflito depende do pensamento oposicional [...]. Na maioria das situações de conflito, duas pessoas querem objetivos opostos e exclusivos. Um vencerá. Outro perderá. [...] Conflito inflama a emoção - raiva, fúria, frustração, sentimentos feridos, sentimento de ser traído, humilhado e ofendido. Essas emoções, uma vez inflamadas, podem ser expressas por meio de gritos, sentimento de traição, de ser menosprezado e ofendido. Tais emoções, uma vez produzidas, podem ser expressas através de gritos, de explosões ou de um soco no nariz de alguém. ${ }^{8}$ (SEGER, 1999, p. 164)

Tanto o conflito exterior entre personagens quanto o conflito entre os desejos e receios no íntimo de um herói incitam à emoção. Um protagonista pode desejar muito algo; mas, ao mesmo tempo, ter medo de realizar esse desejo. Tal conflito interno pode desencadear emoções que se manifestam através do isolamento ou, mesmo, de lágrimas. No caso de Hanna, existe oposição entre seus desejos simultâneos de ser uma adolescente normal e de assassinar sua inimiga Marissa Wiegler. O primeiro desejo está ligado ao aspecto físico da personagem, o de uma adolescente inofensiva, e o segundo é marcado pelas aptidões militares que ela adquiriu ao ser treinada pelo pai. $O$ tema central dos pôsteres promocionais de Hanna está na oposição entre inocência e atos de maldade. Na Figura 6, as características físicas de Hanna evocam uma ideia de inocência que contrasta com a arma que ela exibe. $O$ contraste entre as noções de inocência e violência presentes, ao mesmo tempo, no interior da personagem incita à emoção e à curiosidade do expectador em conhecer a estória da qual ela faz parte.

\footnotetext{
${ }^{7}$ Gives life to drama.

${ }^{8}$ Conflict depends on oppositional thinking [...]. In most conflict situations, two people want opposite and exclusive goals. One will win. One will lose. [...] Conflict ignites emotion - anger, rage, frustration, hurt feelings, feeling belittled and betrayed, put down and insulted. These emotions, once ignited, might find themselves expressed through shouting, blowing up the world, or punching someone in the nose.
} 


\section{Revista do SELL}

v. $4, n^{\circ} .2$

ISSN: $1983-3873$

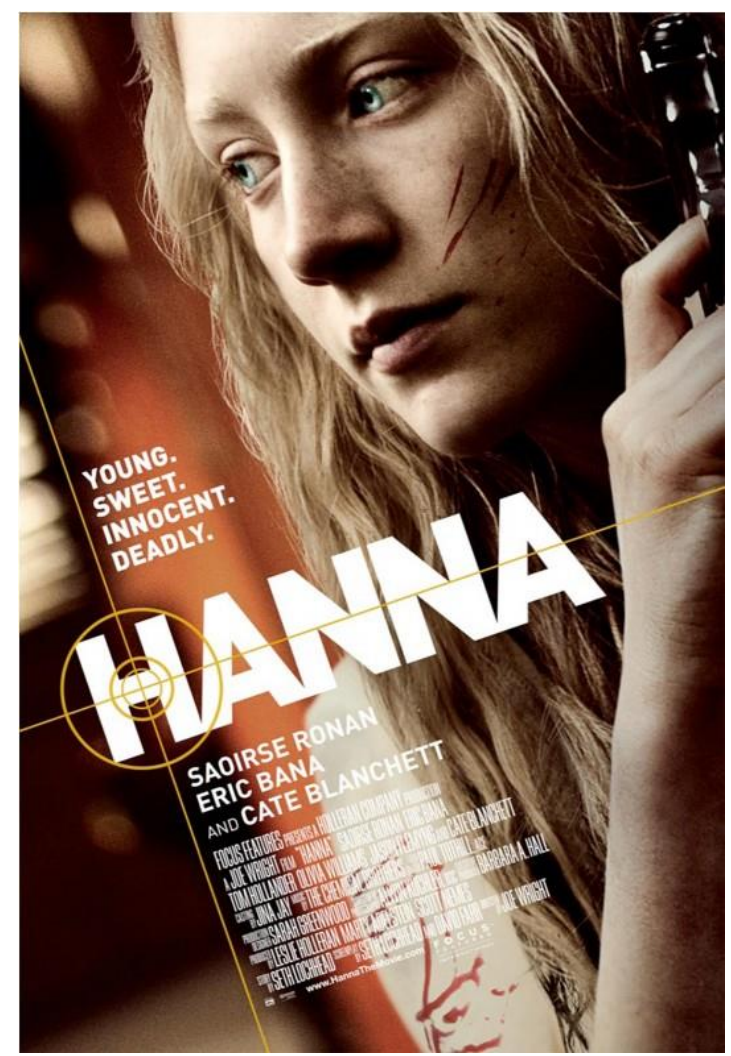

Figura 6: A juventude da protagonista e a arma que ela empunha marcam a oposição entre inocência e violência na figura de Hanna.

HANNA: CARACTERÍSTICAS FISIOLÓGICAS, SOCIOLÓGICAS E PSICOLÓGICAS OPOSTAS.

As informações completas sobre a estória pregressa de Hanna surgem apenas ao final do filme. É a partir do último diálogo entre Hanna e Erik que o formulário com os dados completos sobre a dimensão fisiológica de Hanna pode ser preenchido. As informações contidas nesse diálogo são as que revelam as oposições fisiológicas de Hanna e que, segundo Egri (2004), irão influenciar as demais dimensões - a sociológica e a psicológica — da personagem: 


\title{
Revista do SELL
}

v. $4, n^{\circ} .2$

ISSN: 1983-3873

\author{
ERIK \\ Sente-se. \\ HANNA \\ Você é meu pai? \\ $[\ldots]$ \\ ERIK \\ Sou seu pai, Hanna. Eu te criei. \\ HANNA \\ Mas Marissa disse... \\ ERIK \\ Sou seu pai, Hanna. \\ HANNA \\ Está mentindo para mim. \\ ERIK
}

Sou seu pai. Estive com você toda sua vida. Cuidei de você como se fosse minha própria carne e sangue.

HANNA

Mas eu não sou sua carne e seu sangue. Eu sou uma estranha. Sou anormal.

ERIK

Não.

HANNA

Onde eu nasci? [...] Diga-me a verdade.

ERIK

Num local de pesquisa no interior da Polônia.

HANNA

Qual era a pesquisa?

ERIK

Eles fizeram pequenas mudanças em embriões fertilizados... para melhorá-los. Para reduzir a capacidade para o medo [e de] sentir pena. Aumentar a força muscular. Aumentar os sentidos. Tudo para fazer um soldado melhor. O soldado perfeito. (O eu desanimado de Hanna contradiz tudo o que ele acabou de dizer. Mas ela não consegue ver isso).

\section{ERIK}

Recrutei sua mãe em uma clínica de aborto. Recrutei vinte mulheres da mesma forma.

HANNA

Havia outras crianças? 


\title{
Revista do SELL
}

v. $4, n^{\circ} .2$

ISSN: $1983-3873$

\begin{abstract}
ERIK
Quando você tinha dois anos, Marissa Wiegler fechou o programa. A pesquisa foi descartada. Você entende? Eu te amo demais. Você precisa saber disso.
\end{abstract}

HANNA
Porque sou um super-soldado. Sou uma estranha.

ERIK

Porque você é minha criança.

\section{$[\ldots]$}

ERIK

Eu tentei te preparar para o que seria a sua vida.

HANNA

Você não me preparou para isso. (LOCHHEAD; FARR; 2010, p. 91-93B)

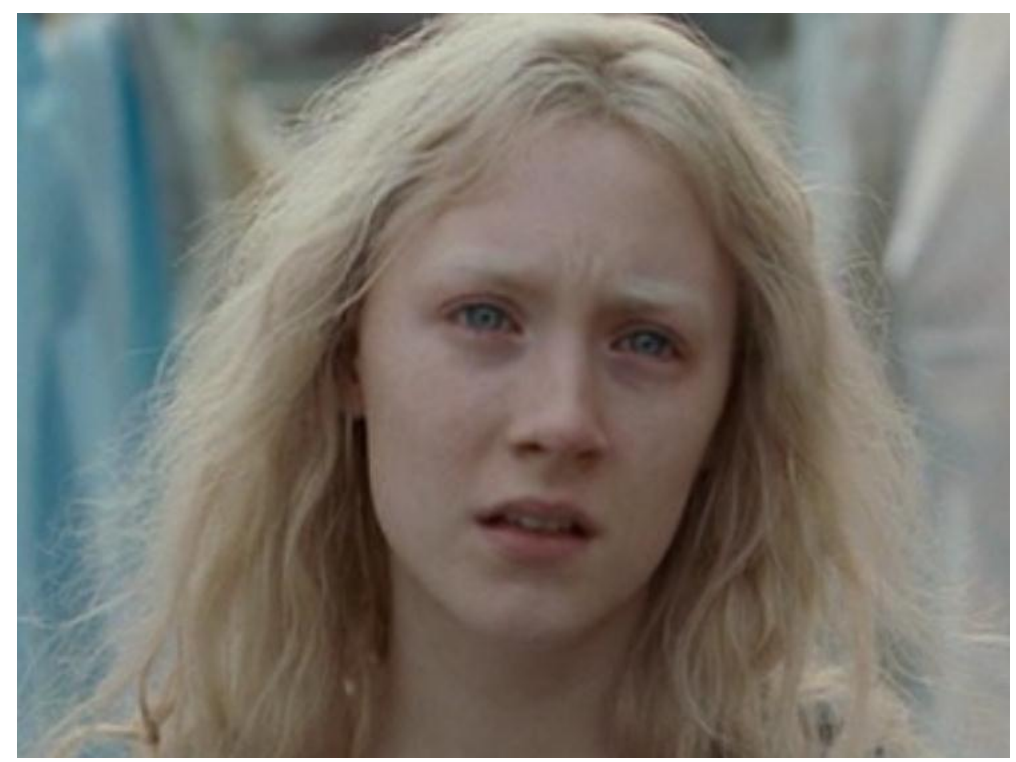

Figura 7: A expressão de Hanna ao dizer "você não me preparou para isso".

A dimensão fisiológica de Hanna contém a oposição que irá influenciar as contradições nas demais dimensões da personagem. Naturalmente emotiva por conta de seu gênero, Hanna é, ao mesmo tempo, geneticamente incapaz de sentir medo e pena. $O$ conflito se instala no interior da personagem porque um de seus maiores desejos é o de cultivar emoções: um conflito, potencialmente, comovente entre desejo e limitação física.

A supressão de emoções na heroína não teria o mesmo impacto em um personagem do gênero masculino. O sinal de que Hanna deseja cultivar suas emoções é 


\section{Revista do SELL}

v. $4, n^{\circ} .2$

ISSN: $1983-3873$

simbolizado pela manifestação de seu desejo de conhecer música, "uma combinação de sons tendo em vista a beleza da forma e a expressão de emoção" (LOCHHEAD; FARR; 2010 , p. 5). A contradição no interior de Hanna, portanto, está na sua "inumana" fisiologia e em seu desejo de cultivar sentimentos e relações humanas. Em dada cena, tal oposição é ainda mais acentuada quando se sabe que, hereditariamente, Hanna poderia ter herdado de sua mãe o dom para a música:

\section{HANNA}

Você conheceu minha mãe também?

KNEPFLER

Mas claro. Ela era uma cantora. Uma cantora maravilhosa. Você canta?

HANNA

Papai-- Erik não me ensinou.

KNEPFLER

Pobre criança! Ele realmente te limitou de todas as coisas maravilhosas que o mundo tem a oferecer. Sem mágica. Sem música. Eu vou te ensinar!

(LOCHHEAD; FARR; 2010, p. 91-93B)

As informações que Hanna adquire acerca de suas características fisiológicas e, em seguida, sociológicas, como a descoberta de que Erik não era seu verdadeiro pai, tem óbvia influência sobre sua dimensão psicológica. Ao término da estória, Hanna é uma personagem transformada; mas, as mudanças que afetam sua dimensão psicológica só ocorrem depois que ela obtém informações sobre suas duas prévias dimensões. Nas tabelas a seguir, são destacadas as novas informações fisiológicas e sociológicas de Hanna e as transformações que elas causam em sua dimensão psicológica:

\section{FISIOLOGIA}

(NOVA INFORMAÇÃO SOBRE A DIMENSÃO FISIOLÓGICA DE HANNA)

\begin{tabular}{|c|c|}
\hline 1. Sexo: & Feminino \\
\hline 2. Idade: & 16 (no roteiro, 14) \\
\hline 3. Altura: & $1.68 \mathrm{~m}$. \\
\hline 4. Cor de cabelos, olhos, pele: & Loiro, olhos azuis, Branca. \\
\hline 5. Postura: & Ereta. \\
\hline
\end{tabular}




\section{Revista do SELL}

v. $4, n^{\circ} .2$

ISSN: $1983-3873$

\begin{tabular}{|c|c|}
\hline 6. Aparência: & $\begin{array}{c}\text { Boa aparência, peso ideal, limpa, } \\
\end{array}$ \\
\hline 7. Deficiência: & $\begin{array}{c}\text { agradável. O desenho da cabeça, da face e } \\
\text { dos membros normal, agradável. Ela tem o } \\
\text { cabelo desarrumado, despenteado. }\end{array}$ \\
\hline & $\begin{array}{c}\text { A CIA alterou seu DNA a fim de aprimorar } \\
\text { seus sentidos, força e estamina, ao mesmo } \\
\text { tempo em que diminuiu sua capacidade de } \\
\text { sentir algumas emoções como pena e } \\
\text { medo. Ela foi parte de um programa } \\
\text { secreto para desenvolvimento de super- } \\
\text { soldados. Esse programa usou mães } \\
\text { recrutadas em clínicas de aborto. }\end{array}$ \\
\hline 8. Hereditariedade: & $\begin{array}{c}\text { Sentidos aguçados, emoções suprimidas, } \\
\text { maior resistência física. }\end{array}$ \\
\hline
\end{tabular}

Tabela 4: Formulário de Egri (2004) preenchido com novas informações sobre Hanna.

\begin{tabular}{c} 
SOCIOLOGIA \\
\hline (ESTADO SOCIOLOGICO DE HANNA DEPOIS QUE NOVAS INFORMAÇÕES SÃO \\
DESCOBERTAS)
\end{tabular}

\begin{tabular}{|c|c|}
\hline 1. Classe: & Baixa. \\
\hline 2. Ocupação: & $\begin{array}{l}\text { Nenhuma ocupação formal. Ela é treinada } \\
\text { para ser uma assassina. }\end{array}$ \\
\hline 3. Educação: & $\begin{array}{l}\text { Nenhuma educação formal. Ela foi ensinada } \\
\text { pelo pai. "Ensinada em saca, Hanna fala } \\
\text { muitas línguas, como Inglês, Alemão, Italiano, } \\
\text { Árabe e Espanhol" (HANNA..., 2012), lê os } \\
\text { contos dos irmãos Grimm, tem vasto } \\
\text { conhecimento enciclopédico de uma } \\
\text { "enciclopédia desatualizada". Ela tem } \\
\text { aptidões de sobrevivência e é "proficiente em } \\
\text { artes marciais, boxe, luta de rua, e armas". }\end{array}$ \\
\hline 4. Vida doméstica: & $\begin{array}{c}\text { Sua mãe está morta. Erik Heller não é seu } \\
\text { pai. Ela se decepciona com ele. Ela é } \\
\text { treinada por um ex-agente da CIA. Hanna é } \\
\text { solteira. }\end{array}$ \\
\hline 5. Religião: & Nenhuma. \\
\hline 6. Raça, nacionalidade: & Branca. Polonesa. \\
\hline 7. Lugar na comunidade: & $\begin{array}{l}\text { Ela vive com seu pai em uma floresta da } \\
\text { Finlândia. }\end{array}$ \\
\hline 8. Afiliações políticas:. & Nenhuma. \\
\hline 9. Diversões, hobbies: & $\begin{array}{l}\text { Ela lê os contos dos irmãos Grimm, } \\
\text { ouve as leituras que seu pai faz de uma } \\
\text { enciclopédia e pratica a caça. }\end{array}$ \\
\hline
\end{tabular}

Tabela 5: Formulário de Egri (2004) preenchido com novas informações sobre Hanna. 


\section{Revista do SELL}

v. $4, n^{\circ} .2$

ISSN: $1983-3873$

\begin{tabular}{c} 
PSICOLOGIA \\
(PERFIL DA DIMENSÃO PSICOLOGICA DE HANNA AO FINAL DA ESTÓRIA) \\
\hline
\end{tabular}

\begin{tabular}{|c|c|}
\hline 1. Vida sexual, padrões morais: & Hanna não tem vida sexual ativa aparente. \\
\hline 2. Premissa pessoal, ambição: & $\begin{array}{c}\text { Hanna, agora, deseja assumir sua } \\
\text { humanidade e jamais matar ninguém } \\
\text { novamente. Agora, ela deve matar Marissa } \\
\text { Wiegler motivada por autodefesa e não por } \\
\text { vingança. Sua motivação para matar } \\
\text { Marissa mudou. }\end{array}$ \\
\hline 3. Frustrações, principais decepções: & $\begin{array}{c}\text { Desapontada com seu pai; decepcionada } \\
\text { com sua condição. }\end{array}$ \\
\hline 4. Temperamento: & Agitado, mas autocontrolado. \\
\hline Ptitude frente a vida: & $\begin{array}{c}\text { Hanna afirma que se sente uma } \\
\text { "aberração", uma pessoa anormal. }\end{array}$ \\
\hline 6. Complexos: & \begin{tabular}{c} 
Sim. \\
\hline 7. Ambiversa.
\end{tabular} \\
\hline 8. habilidades: & $\begin{array}{c}\text { Hanna fala Inglês Alemão Italiano Árabe e } \\
\text { Espanhol. Ela é proficiente em armas e uma } \\
\text { artista marcial talentosa. }\end{array}$ \\
\hline 9. Qualidades: & Imaginação \\
\hline 10. I.Q.: & Nenhuma referência é feita. \\
\hline
\end{tabular}

Tabela 6: Formulário de Egri (2004) preenchido com novas informações sobre Hanna.

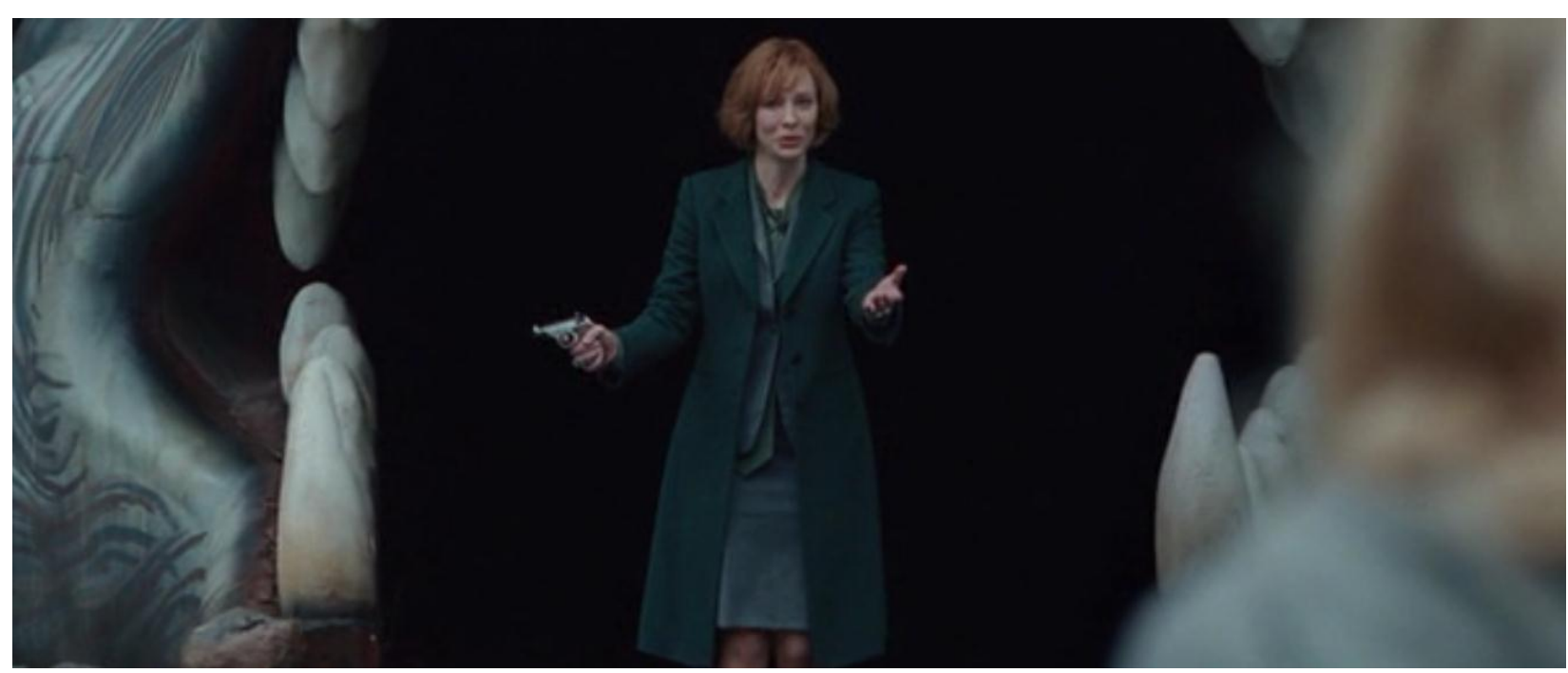

Figura 8: Marissa Wiegler diz a Hanna que pode ajudá-la. 


\section{Revista do SELL}

v. $4, n^{\circ} .2$

ISSN: $1983-3873$

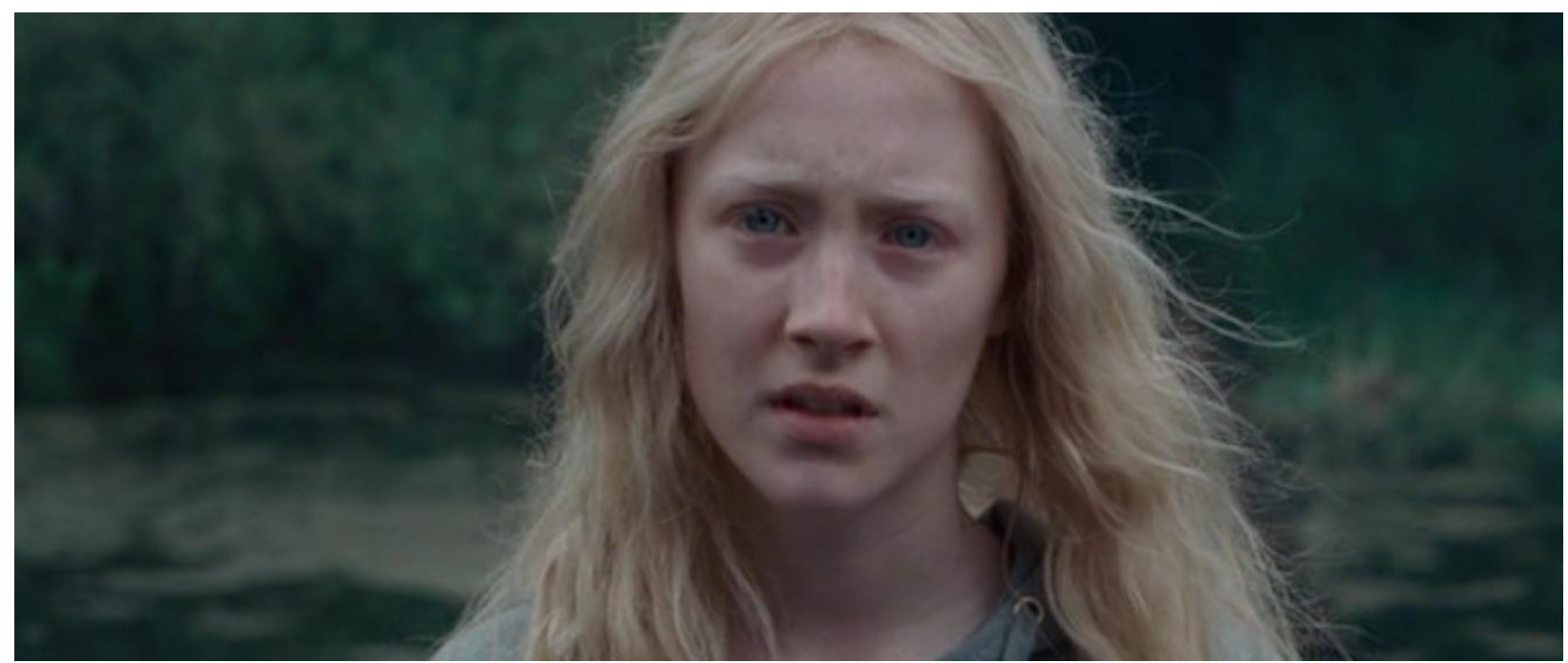

Figura 9: Hanna renuncia a seu desejo de vingança dizendo a Marissa Wiegler que não deseja ferir mais ninguém.

\section{CONFLITO E OPOSIÇÃO EM HANNA}

Hanna é uma personagem com caracterização contraditória; uma heroína cujo desejo de ser uma pessoa comum esbarra na anormalidade de sua condição genética. A emoção, assim como a capacidade dessa personagem de comover o expectador, surge desse conflito interno e que se manifesta, por exemplo, através de suas lágrimas. De acordo com Seger (1999, p. 164), "conflito inflama emoção". 9 Ao descobrir a oposição entre a imagem inicial que tinha de si mesma e sua verdadeira condição, Hanna se sente inferior. Ao final da estória, Hanna é, ao mesmo tempo, uma personagem preparada para matar, mas despreparada para viver. Essa contradição mostra-se dolorida para ela, pois sua condição a faz se sentir tanto marginalizada do mundo do qual esperava fazer parte quanto impossibilitada de ter a vida normal que tanto desejava.

Mesmo "anormal", como a própria Hanna passa a se definir, a heroína ainda tem o potencial de despertar a simpatia do expectador. Personagens que desejam vencer suas próprias limitações ganham a empatia quase imediata do público, ainda que possuam defeitos e que seu passado seja marcado por erros terríveis. Apesar de suas "falhas", Hanna desperta empatia porque deseja aprimorar-se. O publico pode, assim, identificarse com a personagem, uma vez que o desejo de superação constitui uma experiência familiar para a maioria das pessoas.

\footnotetext{
${ }^{9}$ Conflict ignites emotion.
} 


\section{Revista do SELL}

v. $4, n^{\circ} .2$

ISSN: $1983-3873$

Esse estudo trabalhou com a hipótese de que quanto mais características opostas são dadas a um personagem, maior o seu apelo emocional. Cada uma das oposições estudadas corresponde a oposições presentes nas três dimensões da protagonista. Hanna é fisiologicamente contraditória, com traços genéticos que indicam tendências tanto para a emotividade quanto para a frieza de emoções. Em sua dimensão sociológica, há oposição entre o isolamento no qual ela cresce e seu desejo de fazer parte do mundo. Como resultado das duas dimensões anteriores, o conflito na dimensão psicológica de Hanna ocorre entre o que ela acreditava ser verdadeiro acerca de si mesma e o que ela descobre acerca de sua condição.

\begin{tabular}{|c|c|c|}
\hline $\begin{array}{c}\text { (DIMENSÀO FISIOLOGICA) } \\
\begin{array}{c}\text { Gênero feminino } \\
\text { Sensibilidade artística }\end{array}\end{array}$ & $\begin{array}{c}\text { DNA modificado (emoções } \\
\text { suprimidas) }\end{array}$ \\
\hline $\begin{array}{c}\text { (DIMENSÃO SOCIOLÓGICA) } \\
\text { Isolamento }\end{array}$ & $\mathrm{X}$ & $\begin{array}{c}\text { Desejo de fazer parte do } \\
\text { mundo }\end{array}$ \\
\hline $\begin{array}{c}\text { (DIMENSÃO PSICOLÓGICA) } \\
\text { Ideia de pessoa normal e de pai } \\
\text { legítimo }\end{array}$ & $\mathrm{X}$ & $\begin{array}{c}\text { Decepção com a } \\
\text { descoberta de que seu } \\
\text { mundo era uma mentira. }\end{array}$ \\
\hline
\end{tabular}

Tabela 7: As oposições nas três dimensões da personagem Hanna.

O filme Hanna oferece um bom exemplo de construção de uma personagem complexa. Sua heroína não apresenta um único atributo, mas varias características contraditórias que a tornam uma personagem emocionalmente carregada. Suas ações e escolhas derivam necessariamente de uma tensão que amenta os riscos e a importância dessas mesmas ações e decisões. A personagem resultante da aplicação desse processo vem a possuir mais chances de se tornar memorável.

A transformação de Hanna pode ser comprovada por meio da modificação de sua motivação. A oposição entre sua incapacidade para emoção e seu desejo de cultivar 


\section{Revista do SELL}

v. $4, n^{\circ} .2$

ISSN: $1983-3873$

essas emoções através da musica e das relações humanas se resolve com a escolha de oferecer uma chance de sobrevivência à sua inimiga, Marissa Wiegler. Tal gesto marca uma renúncia aos aspectos negativos que ela descobre em si mesma. O desejo primário de Hanna, ao final da estória, não é mais o de vingança, mas o de "entender quem ela é e de onde ela veio" (LOCHHEAD; FARR, p. 101) ${ }^{10}$. E, uma vez em posse dessas informações, tudo o que ela deseja é abraçar sua humanidade.

\section{REFERÊNCIAS}

EGRI, Lajos. The Art of Dramatic Writing. New York: Simon \& Schuster, 1960.

HANNA... Disponível em: <http://www.hannathemovie.com/ - /characters/hanna >. Acesso em 15 Jul 2012.

SEGER, Linda. Making a Good Writter Great. Los Angeles: Silman-James Press, 1999. LOCHEAD, Seth; FARR, David. Hanna. Disponível em: <http://www.focusawards2011.com/workspace/hanna-screenplay.pdf>. Acesso em: 5 Jul 2012.

\footnotetext{
${ }^{10}$ Understand who she is and where she came from.
} 